UDK: 929 Marija Terezija, hrv.-ug. kraljica 94(497.5:436)"1740/1748"

Primljeno: 3. 5. 2018.

Prihvaćeno: 10. 5. 2018.

Izvorni znanstveni rad

DOI: $10.22586 /$ pp.v54i1.72

\title{
Juraj Balic *
}

\section{In her Majesty's Service: Newspaper Reports on the Lycanian Grenzer during the War of the Austrian Succession $(1740-1748)^{*}$}

The regions of Lika and Krbava were among the recent territorial (re)acquisitions of the Habsburg rulers following the Great Turkish War or the War of the Holy League (1683-1699). Incorporation of these regions into the Croatian-Slavonian Military Frontier presented a great difficulty to the Habsburg authorities because of the defiant nature of their inhabitants, who persistently defended their rights and privileges. Like many other Grenzer, the Lycanians, as they were referred to in the contemporary British newspapers, initiated revolts whenever they felt that their privileged status might be endangered. Nonetheless, these and other Grenzer troops not only defended the Habsburg borders from the Ottomans, but also fought for their rulers all across Europe. The aim of this paper is to examine the role and success of these particular Grenzer during the War of the Austrian Succession (1740-1748). The main focus will be on their depiction in the contemporary British and Austrian newspapers which followed the actions of various combatants during the mentioned conflicts.

Keywords: Grenzer, Military Frontier, Lika and Krbava, Maria Theresia, War of the Austrian Succession, early modern newspapers, early modern warfare

Prolonged and large-scale warfare constituted an important part of the reign of Maria Theresia (1740-1780). As she was about to ascend the throne and claim the inheritance of her father, Emperor Charles III (1711-1740), she had to face the

Juraj Balić, Croatian Institute of History, Opatička 10, 10000 Zagreb, Croatia, E-mail: jura.balic@ gmail.com

** This paper was co-financed by the Croatian Science Foundation under the project number 3675. 
aggravating problem of protecting her domains against the neighbouring rulers, most notably Frederick II of Prussia (1740-1786) and Charles Albert of Bavaria (1726-1745), who did not recognize her claim to the inheritance. In order to confront her enemies and defend her positions, Maria Theresia had to rely heavily on the armed forces at the Habsburg disposal. These included troops recruited from various domains that recognized the Habsburg rule, including the Military Frontier. This region, located alongside the Habsburg-Ottoman border, was initially designed as a zone of defence against the Ottoman incursions, but from around the middle of the $18^{\text {th }}$ century was assigned the additional role of supplying the Habsburg armed forces with manpower to be used in various wars, waged predominantly on the territory of the Holy Roman Empire.

During the War of the Austrian Succession (1740-1748), various parts of the Military Frontier underwent a process of reform, resulting in the creation of "Grenzer regiments," which were not only military, but also territorial and administrative units. The Croatian and Slavonian parts of the Military Frontier were consequently divided into eleven Grenzer regiments. One of them was the Lika Regiment, which encompassed the area of the contemporary regions of Lika and Krbava.

The aim of this paper is to follow the exploits of the Grenzer from the Lika Regiment during the above-mentioned conflict. The main primary source for this purpose will be reports published in the contemporary British and Austrian newspapers. These newspapers followed closely the said military endeavours and provide valuable evidence on the activities of different military troops, including the Grenzer. By analysing the content of newspaper articles, this paper will offer possible explanations of the role, perception, contribution, and location of Grenzer from the Lika Regiment during the war which brought into question Maria Theresia's rule and the existence of the Habsburg Monarchy.

\section{The Lika Regiment}

Defeat of the Ottoman forces in the Battle of Vienna on December 12, 1683 initiated the offensive of the Habsburg forces with their allies, which would be known as the Great Turkish War (1683-1699). During this conflict, many lands under the Ottoman rule were (re)conquered, amongst them Lika and Krbava, former parts of the Kingdom of Croatia. The first to take the initiative were the Christian inhabitants of these regions, which took up arms against the Ottomans. These uprisings were followed by incursions of various groups from the Military Frontier, more precisely the Karlstadt Generalate. In 1685, General Johann Joseph Herberstein (1669-1689) conducted a campaign with the intent of raiding and spreading terror among the Ottoman subjects. Finally, in spring 1689, the afore-mentioned Karlstadt general, in cooperation with various groups of volunteers, launched a 
campaign aimed at driving the Ottomans out of these lands, a mission that was successfully concluded by the summer of the same year. ${ }^{1}$

Even before the war was officially over, the newly acquired lands of Lika and Krbava were designated to be organized in a new fashion. The plan envisaged that the population inhabiting these regions would be subjected to the military officials of the Karlstadt Generalate in military affairs, while in judicial, administrative, and economic matters they would answer to the Hofkammer, the main financial institution of the Habsburg Monarchy and the official owner of the newly acquired territories, or to a particular feudal lord who would purchase these lands from the Hofkammer. The populace, as well as the military officials, displayed discontent with this dual system of government. The military officials were deprived of various sources of income, such as judicial fines or bribes linked to the allocation of land, while the populace resented the idea of being obliged to pay feudal dues. Thus, several minor revolts broke out in 1692, 1693, 1702, 1704, and 1711. Among the main causes for these uprisings were the people's grievances with the misrule of the governing officials, as well as their rejection of the implementation of serfdom and the feudal dues. The inhabitants demanded that they be awarded the Grenzer status and that the region be incorporated in the Military Frontier. Ultimately, the authorities in Vienna capitulated in 1712, granting the population of Lika and Krbava the Grenzer status and annexing these regions to the Karlstadt Generalate. ${ }^{2}$

During the first half of the $18^{\text {th }}$ century, the Grenzer of Lika and Krbava continued to stir up rebellions whenever they felt that their privileged status might be endangered by the introduction of reforms. This was the case in 1728 and 1732, when the Grenzer rebelled against the mistreatments of the military officials and because of the rumours that they would lose their privileged status and be turned into serfs. It is important to emphasize that the rebellion did not involve the whole region, but only several villages. It was swiftly suppressed, the ringleaders were executed in a cruel fashion and their property confiscated, but the rest of the

\footnotetext{
1 For more details regarding the military campaigns in Lika and Krbava during the Great Turkish War, see Rudolf Horvat, Lika i Krbava: povijesne slike, crtice i bilješke, ed. Nikola Bićanić (Zagreb: Savez hrvatskih ličkih zavičajnih klubova "Vila Velebita", 1993), 36-39; Ivan Jurišić, "Lika i Krbava od Velikog rata za oslobođenje do inkorporacije u Karlovački generalat (1683-1712)", Radovi - Zavod za hrvatsku povijest 37 (2005): 101-102; Milan Kruhek, “Turske utvrde i kule u Lici i Krbavi 1527. - 1689. godine”, Senjski zbornik 40 (2013): 489-490, 492-499, 504-505; Mirko Marković, Ličani kroz prošlost (Zagreb: Naklada Jesenski i Turk, 2001), 87-90; Gunther Eric Rothenberg, The Austrian Military Border in Croatia, 1522-1747 (Urbana, IL: The University of Illinois press, 1960), 89-90.

2 Cf. Stjepan Antoljak, Bune pučana i seljaka u Hrvatskoj (Zagreb: Matica hrvatska, 1956), 221-228; Ferdo Čulinović, Seljačke bune u Hrvatskoj (Zagreb: Seljačka sloga, 1951), 83-87; Željko Holjevac, Brinjsko-lički ustanak 1746. godine (Samobor: Meridijani, 2004), 38-39; Horvat, Lika i Krbava, 46-47; Jurišić, "Lika i Krbava”, 101-106; Fedor Moačanin, Mirko Valentić, Vojna krajina u Hrvatskoj (Zagreb: Povijesni muzej Hrvatske, 1981), 32.
} 
Grenzer who participated in the rebellion were pardoned and no changes were made regarding their status. ${ }^{3}$

Because of this unwillingness to accept changes, the Grenzer retained a negative image in the eyes of their officers, who perceived them as defiant and unruly. On the other hand, the military authorities recognized the military capabilities of the Grenzer and decided to employ them as irregular troops not only in the wars waged against the Ottomans, ${ }^{4}$ but also in other wars, far away from the confines of the Military Frontier. The first opportunity to test this plan occurred during the War of the Polish Succession (1733-1738) when the Grenzer troops, including the ones from Lika and Krbava, were sent to the Apennine Peninsula. The military authorities foresaw that they serve only for a period of six months, in order not to jeopardize the agricultural production of the Military Frontier. ${ }^{5}$

Even though the Grenzer proved their value as excellent irregular soldiers, the Austrian military officials usually complained of their lack of discipline. During the second quarter of the $18^{\text {th }}$ century, new steps were undertaken to introduce reforms with the aim of disciplining the Grenzer and turning them into regular soldiers. After some unsuccessful attempts in the Karlstadt and Warasdin Generalates, ${ }^{6}$ the task of developing a model for reform was assigned to Prince Joseph von Sachsen-Hildburghausen (1702-1787). He began his work in the Warasdin Generalate and completed it in 1737 by promulgating a new statute, intended to introduce significant military, judicial, administrative, and economic changes. The main aim behind these reforms was to create inexpensive and efficient Grenzer soldiers who could be employed against all the Habsburg enemies at all times. Unfortunately, the implementation of these reforms was postponed due to the outbreak of the Austro-Turkish War of 1737-1739.?

\footnotetext{
3 Cf. Antoljak, Bune pučana i seljaka, 229, 231-233; Čulinović, Seljačke bune, 91-95; Holjevac, Brinjsko-lički ustanak, 40-41.

4 The Genzer of Lika and Krbava participated in the Austro-Turkish war of 1716-1718 and the Austro-Turkish War of 1737-1739. Cf. Alpfhons Freiherr von Wrede, Geschichte der k. und k. Wehrmacht. Die Regimenter, Corps, Branchen und Anstalten von 1618 bis Ende des XIX. Jahrhunderts, V. Band (Vienna: Seidel, 1903), 209, 211; Franz de Paula Julius Fras, Cjelovita topografija Karlovačke vojne krajine (Gospić: Ličke župe, 1988), 125, 136-137, 150.

5 Rothenberg, The Austrian Military Border, 110-111. Wrede, Geschichte der k. und k. Wehrmacht, 211, n. 1 and 2.

6 Rothenberg, The Austrian Military Border, 108-109; Wrede, Geschichte der k. und k. Wehrmacht, 215, n. 3 .

7 For more detailed information regarding Hildburghausen's reform plan, see Ivan Jurišić, Karlovački generalat u reformama Habsburškoga dvorskog apsolutizma. Primjer Hildburghausenovih reformi (1737.-1749.) (doctoral dissertation, University of Zagreb, 1998), 66-79; Moačanin, Valentić, Vojna krajina u Hrvatskoj, 35; Rothenberg, The Austrian Military Border, 112-118; Gunther Eric Rothenberg, The Military Border in Croatia, 1740-1881: A Study of an Imperial Institution (Chicago; London: The University of Chicago Press, 1966), 15-16.
} 
The process of reforming the Croatian-Slavonian Military Frontier was resumed during the first years of Maria Theresia's reign. In 1744, she placed Hildburghausen at the head of the Militär Direktorium, a newly established institution responsible for the reorganization of the Karlstadt and Warasdin Generalates. Hildburghausen set on to work at once and concluded it, in the former Generalate, in 1746. The main changes entailed the abolishment of the old captaincies and the establishment of regiments as military and administrative units. The Lika Regiment, ${ }^{8}$ encompassing the Lika and Krbava County, was the largest of the four regiments within the Karlstadt Generalate. ${ }^{9}$

Other distinguishing features of the reform included the introduction of draconian measures of punishment in order to discipline the "crude" and "wild" Grenzer. However, considerations regarding the Frontier's security and agricultural production were also taken into account. Therefore, in case of mobilization, the Grenzer were divided into three squads: one was sent to the battlefield, the second was in charge of securing the borders, and the third was responsible for cultivating the land. Even though the Grenzer were equated with other regular soldiers in the Austrian army in terms of status, because of their traditions and habits they continued to be employed as light infantry troops. ${ }^{10}$

The implementation of reforms did not, however, proceed as smoothly as anticipated. Late in July 1746, when most of the reform work was concluded, a rebellion broke out in some parts of the Karlstadt Generalate, including the Lika Regiment. Its main initiators were some officers and village elders who felt that the new system deprived them of valuable sources of income and power. Just about the time a large contingent was supposed to be sent to the battlefront, false rumours spread among the Grenzer. As usual, they included news about the alleged introduction of additional feudal dues and threats that their lands and families would not be safe during their absence. The rebellion did not last very long and after other Grenzer from the Lika and Otočac Regiments refused to join in, the malcontent Grenzer returned to their homes. As before, the ringleaders were se-

\footnotetext{
8 Initially, infantry regiments were named after their colonel-proprietors. In case of the Lika Regiment, it was Count Joseph Philipp von Guicciardi (Quicciardi). From 1753, the regiments took the names of their headquarters or districts. Cf. Jurišić, Karlovački generalat, 157; Rothenberg, The Military Border, 22; Wrede, Geschichte der k. und k. Wehrmacht, 215, n. 7.

9 In theory, each regiment consisted of twenty companies, which meant that it could provide 4,000 armed men. Naturally, in practice the actual number was much lower. While the other three regiments of the Karlstadt Generalate formed four battalions each, the Lika Regiment consisted of six battalions and numbered around 9,000 men. Additionally, 200 hussars were recruited in this region and formed one out of four squadrons of the Karlstadt Hussar Regiment. Wrede, Geschichte der k. und k. Wehrmacht, 215, n. 7 .

10 For more detailed information concerning the reforms of the Croatian-Slavonian Military Border instigated by Hildburghausen, see Jurišić, Karlovački generalat, 95-157; Rothenberg, The Austrian Military Border, 120-122; Rothenberg, The Military Border, 21-24.
} 
verely punished by execution or life-long imprisonment and the confiscation of property. ${ }^{11}$

\section{Characteristics of eighteenth-century warfare}

One of the main features of early modern warfare was constant shift in the military tactics, as the art of warfare was adapted to the various needs and demands of the opposing sides. This was certainly the case with the Habsburg Monarchy during the War of the Austrian Succession. The dire need to answer the challenges posed by fighting multiple enemies on various sides encouraged the Austrians to recruit as many armed men as possible. Among these, the Hungarian hussars and the irregular Grenzer from the Military Frontier were among the most extraordinary, but also considerably useful troops. As Armstrong Starkey points out: "These hussars, Croats, and Pandours, as they were known, played havoc with Frederick's vulnerable communications and logistics and played no small part in the preservation of the monarchy." 12

At the beginning of the War of the Austrian Succession, the Austrian army was in a poor state. According to Christopher Duffy, Maria Theresia "inherited an army which bore less resemblance to a fighting force than to some horrid object that was preserved as a lesson in every ill capable of infecting a military organism." 13 Therefore, she dedicated herself to her soldiers as an attentive parent by initiating a set of military reforms supposed to introduce discipline and new tactics, as well as improve the clothing and equipment of the Austrian troops. ${ }^{14}$ Although most of the military reforms were introduced after the peace of Aix-laChapelle in 1748, the experience of the War of the Austrian Succession, particularly the Austrian defeats at Mollowitz in 1741 and Hohenfriedberg and Soor in 1745 , revealed the flaws in the Austrian army and its inferiority to the Prussian forces. Before the beginning of the Seven Years' War (1756-1763), Maria Theresia created a new Austrian army ${ }^{15}$ with new grenadier companies separated from

\footnotetext{
11 For more details regarding the causes, participants, and course of the rebellion, see Antoljak, Bune pučana i seljaka, 236-241; Čulinović, Seljačke bune u Hrvatskoj, 98-101; Holjevac, Brinjsko-lički ustanak, 57-85; Jurišić, Karlovački generalat, 158, 193, 195-196, 199-201, 204, 209-211, 217.

12 Armstrong Starkey, War in the Age of Enlightenment, 1700-1789 (Westport, CT: Paeger 2003), 53. These light troops were one of the three crucial innovations in early modern military thought, besides the introduction of divisional organization and the creation of a swift and mobile field artillery, which Geoffrey Parker has labelled as "the military post revolutions." Cf. Jeremy Black, European Warfare, 1660-1815 (London: University College London, 1994), 125.

13 Christopher Duffy, The Army of Maria Theresa: The Armed Forces of Imperial Austria, 1740-1780 (North Pomfret, VT: David \& Charles, 1977), 145.

14 Duffy, The Army of Maria Theresa, 18.

15 The term "Austrian army" emerged also a consequence of the War of the Austrian Succession. For simplicity's sake, the royal Bohemian and Hungarian army came to be referred to as "Austrian." Even
} 
the infantry regiments, lighter uniforms that offered better protection from wet and cold weather, a more effective type of muskets, and new military drills. The military reforms of Maria Theresia also changed the views concerning the military profession - from a mercenary trade to an honourable and promising occupation - and created a professionalized army that would remain closely linked to the ruling dynasty for more than a century. ${ }^{16}$

Even though the above-mentioned changes came into effect during the second great conflict which marked Maria Theresia's reign, some of them appeared during the War of the Austrian Succession. For instance, the grenadiers, as will soon be observed, were now often used in combination with the Grenzer troops. ${ }^{17}$ Furthermore, the reform of the Croatian-Slavonian Military Frontier took place during the mentioned conflict. Therefore, the War of the Austrian Succession may have served as a testing ground for many military innovations that would be officially implemented shortly after its end. One of these was certainly la petite guerre or "small-war" tactics, with the irregular troops, most notably the Grenzer, as its main protagonists. According to Reed Browning, their role was neglected during the $18^{\text {th }}$ century and gained recognition only during the Napoleonic wars. As a reason for this phenomenon, he has noted that the participation of irregular troops was usually overshadowed by the public opinion, which did not regard them as honourable soldiers. ${ }^{18}$

Nonetheless, light troops played an important role in $18^{\text {th }}$-century warfare, especially in the Austrian armies. Their main features included their ability to move rapidly and to cut off the enemies' supply lines, as well as their self-sustainability. However, even though they were successful in performing various military tasks, they were disdained by the Austrian foes, such as the French and the Prussians, who disparaged them as adventurers, deserters, and vagabonds. Interestingly, this

when Maria Theresia's husband, Franz Stephan von Lothringen (1708-1765), was crowned Holy Roman Emperor in 1745, thus returning the Imperial insignia to the House of Habsburg, the terms "Imperial army" and "Austrian army" were fused together and Europe became accustomed to referring to the Habsburg armies as "Austrian." Cf. Richard Basset, For God and Kaiser: The Imperial Austrian Army from 1619 to 1918 (New Haven, CT: Yale University Press, 2015), 95, 108; Duffy, The Army of Maria Theresa, 17.

${ }_{16}$ For detailed information regarding the military reforms of Maria Theresia, see Basset, For God and Kaiser, 90, 106, 109, 117-119; Black, European Warfare, 129-131.

${ }_{17}$ Grenadiers were tall, strong, and bold men, distinguished by their lofty bearskin headdresses, ferocity, and curved sabres. They were introduced in the Austrian army at the beginning of the $18^{\text {th }}$ century and used as shock troops, capable of hurling grenades at the enemy. After the War of the Austrian Succession, the grenadier companies were detached from the infantry regiments and established as separate elite units, while in case of the Karlstadt Generalate, each Grenzer regiment was strengthened by adding two grenadier companies. Cf. Basset, For God and Kaiser, 116-117; Duffy, The Army of Maria Theresa, 63-64, 70; Jurišić, Karlovački generalat, 172.

18 Reed Browning, "New Views on the Silesian Wars," The Journal of Military History 69 (2005), nr. 2: 531-532. 
did not prevent the Austrian opponents from incorporating light troops within their own armies, for example the French chasseurs and the Prussian Jäger. ${ }^{19}$

It is also important to highlight the fact that early modern warfare was distinguished by a high degree of violence. Devastation, pillage, rape, and murder were integral components of numerous military actions. Undisciplined soldiers were often victims of furious armed peasants seeking retribution..$^{20}$ Sustaining the armed forces, even regular ones, relied heavily on the tax system, imposing a war tax on the populace of the region occupied by a particular army. Even though its aim was to limit the degree of violence inflicted by the soldiers on the common folk, collection of this tax was occasionally followed by violent acts. These circumstances contributed to the negative perception of the soldiers among the civilian population. ${ }^{21}$ This fear and hatred was especially directed at the irregular soldiers, who were required to sustain themselves by means of plunder.

Lastly, violent acts during the War of the Austrian Succession were committed by both opposing sides. The British forces plundered the Rhineland, the Prussians were merciless during their occupation of Bohemia and Saxony, the French were notorious for their barbaric conduct towards the civilian populations, and the Austrian regular troops were responsible for the mistreatment of civilians on the Ligurian coast. ${ }^{22}$

\section{The Grenzer in contemporary newspapers}

The activities of the Grenzer troops during the War of the Austrian Succession were recorded by the Viennese newspaper Wienerisches Diarium, one of the oldest newspapers in the world that is still published today. However, a significantly larger interest for tales of the military exploits of these troops was shown by the British newspapers, in the capital and the countryside alike. The prominent London newspapers The London Gazette, The St. James's Evening Post, and The London Evening Post intensively published reports about Maria Theresia's irregulars, and so did the British provincial newspapers, such as The Aberdeen Press and Journal, The Derby Mercury, The Newcastle Courant, The Caledonian Mercury, The Ipswich Journal, The Stamford Mercury, or The Scots Magazine, which usually transmitted the news from the London newspapers or from other foreign sources.

\footnotetext{
19 Michael Howard, Rat u europskoj povijesti, trans. Magdalena Najbar-Agičić (Zagreb: Srednja Europa, 2002), 89-90.

20 Starkey, War in the Age of Enlightenment, 138-139.

21 Julius Ruff, Violence in Early Modern Europe (Cambridge: Cambridge University Press, 2001), 44.

22 Basset, For God and Kaiser, 108.
} 
By the middle of the $18^{\text {th }}$ century, journalism had achieved a considerable success in Great Britain. At that time, there were eighteen newspapers published in London alone, while forty newspapers were recorded in the provinces. Regarding the circulation of newspapers, there were about 100,000 copies printed in London and about 9.4 million in the whole country. ${ }^{23}$ During the course of the century, British readership became more numerous and more socially diverse. Even illiteracy did not present an obstacle for groups of individuals to familiarize themselves with the latest news. As a common practice, newspaper articles were read aloud in private homes or public places, such as pubs, coffee houses, stores, and reading rooms. ${ }^{24}$

An obvious reason why the publishers of British newspapers displayed such interest for the Austrian irregular soldiers may be found in the fact that Great Britain was an ally of the Habsburgs during the mentioned war. ${ }^{25}$ Another possible reason might be their application of a revolutionary style of warfare, namely, the "guerrilla" or "small-war" tactics. Furthermore, the activities of irregular units in general, such as the Highlanders or the French Grassins and Pandours, were particularly interesting because the enterprises of these troops were often accompanied by immense material rewards. Besides the tales of riches, the public was also drawn by the descriptions of violent behaviour, which included murders, rapes, and pillaging, ${ }^{26}$ and were often attributed to soldiers, especially the irregular ones.

The official government newspaper, The Gazette, informed the public about the events on the Continent by publishing foreign diplomatic and war reports, as well as accounts by eyewitnesses, mostly soldiers and officers. These reports were supplemented by articles from foreign newspapers and letters written by merchants and travellers. Because of the great distances and difficulties in communication, such news could be outdated and not entirely true, but remarkably, the British newspapers were distinguished by a high degree of objectivity. This can be no-

${ }^{23}$ Hannah Barker, Newspapers, Politics and English Society 1695-1855 (Harlow: Pearson Education, 2000), 29-31.

24 Barker, Newspapers, Politics and English Society, 63.

25 It is important to remark that at the start of the war Great Britain, even though it displayed support for Maria Theresia's cause, took a neutral stand. One of the reasons lay in the possible danger for Hanover, which was in possession of the British monarch George II (1727-1760), from an anticipated French and Prussian attack. In 1741, George II, as Prince-Elector, even promised to support Charles Albert, the Prince-Elector of Bavaria, in his claim for the imperial crown. Finally, in 1743, British military support was procured. For more details concerning the British policy toward the Habsburg Monarchy in the first years of the war, see Reed Browning, The War of the Austrian Succession (New York: St Martin's Press, 1993), 48-51, 61-62, 64-65, 71, 99-102, 113-114, 134-135; Michael Hochedlinger, Austria's Wars of Emergence: War, State and Society in the Habsburg Monarchy 16831797 (London: Pearson Education, 2003), 249-252.

26 Ruff, Violence in Early Modern Europe, 27, 39. 
ticed in the words of praise and admiration with which the articles described the courageous and heroic deeds of their enemies, notably the French. ${ }^{27}$

The most frequent term used to denote the Grenzer troops in the British newspapers was Croats, regardless of the religion or ethnicity of the Grenzer groups in question..$^{28}$ Simultaneously, a similar feature occurred regarding the Habsburg military forces, which were now labelled as "Austrian", as explained earlier in this text. Thus, it is often difficult to distinguish to which Grenzer regiment the "Croats" mentioned in a specific article belonged to. However, it is possible to solve this problem if their commander, usually a colonel or colonel-lieutenant, is mentioned, although this does not necessarily have to be entirely trustworthy. Luckily, the newspapers also use other terms, which denote the Grenzer belonging to a specific region of the Military Frontier. Mostly this refers to the Karlstadt or Warasdin Generalates, or the Slavonian or Banate Frontiers. However, since the County of Lika and Krbava presented a specific region within the Karlstadt Generalate until the reform of 1746, the newspapers used specific terms for the Grenzer from this part of the Military Frontier. The most common one was Lycanians. Others, less frequent ones, include Licanians, Licanions, and Lycamans, while in the Wienerisches Diarium they are referred to as Liccaner.

\section{The Lycanians during the first years of the war (1741-1743)}

In 1741, numerous Grenzer troops from various parts of the Croatian-Slavonian Military Frontier were present in Silesia, Bohemia, Bavaria, and the Apennine Peninsula. The arrival of Grenzer from Lika is recorded in Bavaria in autumn 1741. During the following year, they were dispersed in various theatres of war, probably in accordance with the Austrian strategy not to keep large numbers of the same Grenzer type, or large numbers of Grenzer in general, in a single area because of the difficulties in controlling these men. In Bavaria, the Grenzer from Lika participated in victorious battles alongside the Pandour Freikorps of the famous Baron Franz von der Trenck (1711-1749). In Bohemia, they thwarted the advance of the Prussian forces and performed assaults on forts occupied by the French. In June 1742, they scaled the walls of Pisék and in November of the same year the walls of Litomerrice. Some of them were despatched to Italy, where they fought alongside the Grenzer from other parts of the Croatian-Slavonian Military Frontier. ${ }^{29}$

\footnotetext{
27 Barker, Newspapers, Politics and English Society, 105-106.

28 Starkey, War in the Age of Enlightenment, 139.

29 Ivan Kukuljević Sakcinski, Hrvati za nasljednoga rata (Zagreb: Dionička tiskara, 1877), 10, 12-13, $14-16,18,22$.
} 
The first newspaper report concerning the activity of the Grenzer from Lika dates from July 28, 1742..$^{30}$ The report informed that they were located just in front of Prague, where the Austrian besiegers intended to drive out the French occupants. The Grenzer forces, mentioned as the Croats and the Lycanians, were posted near the city and performed surprise attacks on the small islands located on the river Vltava. ${ }^{31}$ The following month they were engaged in various activities common to the siege warfare. For instance, they had to stay alert to prevent surprise attacks from the besieged forces. Such an event occurred during the night of August 6-7, 1742. Even though the enemy's overpowering force almost compelled the Grenzer and the hussars to abandon their post, these light troops were able, with the support of the grenadiers, to repel the enemy. ${ }^{32}$ Examples of such combined use of Grenzer light infantry, hussar light cavalry, and elite grenadier shock troops would become a common feature during this war.

That same month, the Lycanians were also engaged in missions aimed at clearing the French posts around Prague, which they successfully performed, forcing the enemy to retreat to the city. ${ }^{33}$ However, an article published in The Derby Mercu$r y$ reveals that the Grenzer occasionally required a special stimulus in order to perform a task. Such was the case of September 1, 1742 when the Feldmarschall Prince Charles of Lorraine (1712-1780) offered a reward of 200 ducats for attacking the French forces preventing the Austrian sappers from doing their work in front of the gate Strohoffer. ${ }^{34}$ The Lycanians accepted the offer and successfully executed the mission, returning to Prince Charles with four captured field pieces and seven French prisoners. ${ }^{35}$

In 1743, the Grenzer of Lika were part of the army under the command of Prince Johann Georg Christian Lobkowitz (1686-1755). The army was located in Bohemia, but since after the peace treaty with Prussia the northern borders of the Habsburg Monarchy were secure, all available forces were transferred to Bavaria.

\footnotetext{
30 The dates in the British newspapers are written in the "Old Style" (OS). After the Gregorian reform, Great Britain continued to use the Julian calendar until 1752, when it switched to the reformed calendar. The dates of reports published in the newspapers vary. Occasionally, there is an indicator which reveals whether the date is written in the "Old Style" or "New Style" (NS), but often this indicator is missing. In that case, the assumption is that the style in which the dates were written refers to the place, i.e. country, from which the report originates.

31 The Stamford Mercury (Stamford), online version, August 12, 1742 (OS), 1, https://www.britishnewspaperarchive.co.uk/ (last accessed on January 25, 2017).

32 Wienerisches Diarium (Vienna), online version, August 18, 1742, 9-10, http://anno.onb.ac.at/ (last accessed on March 6, 2017).

33 Wienerisches Diarium (Vienna) online version, August 22, 1742, 15-16, http://anno.onb.ac.at/ (last accessed on March 6, 2017).

34 Strohoffer Tor was the city gate of Prague.

35 The Derby Mercury, online version, September 16, 1742 (OS), 3, https://www.britishnewspaperarchive.co.uk/ (last accessed on January 16, 2017).
} 
There, Grenzer from Lika participated in the capture of strongholds defended by the Bavarian and French troops, such as Auerberg, Deggendorf, Landshut, and Ingolstadt. ${ }^{36}$ Even though the customary narrative suggests that the Grenzer captured these towns single-handedly, the newspapers reveal what their task specifically was. For example, in case of Deggendorf, located near the Bohemian border, ${ }^{37}$ they were assigned the task of clearing the French entrenchments located in front of the town, as the army of Prince Lobkowitz was approaching. They successfully performed this task and forced the enemy to retreat behind the town walls. The article stresses the fact that most of the enemy soldiers were "put to the sword, except a very few, whom they made prisoners," as well as that the Lycanians gained war trophies, including three kettle drums, 120 muskets, and 25 horses. ${ }^{38}$ This information was meant to highlight the fact that they were irregular troops, entitled to spoils of war and prone to violent behaviour. However, the article also points out that these irregulars accomplished a dangerous and important mission crucial for making the necessary preparations for a siege or assault on a city.

In the late spring of 1743, the Austrian forces were pursuing the French, who were retreating westward along the Danube. In these circumstances, the rapid mobility of the Austrian irregular troops was put to use. Evidence of their success can be found in the British newspapers, which inform about the "Hussars, Croats and Pandours" harassing the retreating French and claiming their baggage. ${ }^{39} \mathrm{~A}$ report from Ratisbon ${ }^{40}$ dated June 2, 1743 informs that after the capture of the castle Weix, Prince Lobkowitz dispatched " 4000 Croatians, Pandours and Licanians" towards Kelheim. As soon as these troops approached their destination, the French garrison set fire to the bridge. Obviously, they were trying to slow down the advance of the Austrian irregulars and enable the French forces under Marshal Broglie to reach Ingolstadt. ${ }^{41}$

\footnotetext{
${ }^{36}$ Kukuljević Sakcinski, Hrvati za nasljednoga rata, 32-33.

37 Interestingly, Reed Browning states that, in contrast to the "Croats in the Austrian army" who were wreaking havoc on civilians in Bavaria, on May 27 "Count Browne's more disciplined force took Deggendorf". Browning, The War of the Austrian Succession, 136. This suggests that there was possibly a different viewpoint concerning the distribution of violence. In case of civilians, it was condemned, but in case of combatants it was tolerated.

38 The Ipswich Journal (Ipswich), online version, May 28, 1743 (OS), 3, https://www.britishnewspaperarchive.co.uk/ (last accessed on January 16, 2017).

39 The Ipswich Journal (Ipswich), online version, June 11, 1743 (OS), 3, https://www.britishnewspaperarchive.co.uk/ (last accessed on January 25, 2017).

${ }^{40}$ An old English name for Regensburg.

${ }^{41}$ The Ipswich Journal (Ipswich), online version, June 11, 1743 (OS), 3, https://www.britishnewspaperarchive.co.uk/ (last accessed on January 25, 2017); The Derby Mercury (Derby), online version, June 16, 1743 (OS), 3, https://www.britishnewspaperarchive.co.uk/ (last accessed on January 25, 2017).
} 
Around the same time, there are reports of large numbers of Grenzer, including the ones from Lika, moving through Bavaria. A report of " 80,000 Hussars, Croats, Warasdiners, Lycanians, Illyrians, and Pandours" marching from Hungary to Bavaria $^{42}$ suggests that these figures were slightly exaggerated, but it also reveals that the Austrian military authorities required large numbers of combatants to continue their successful offensive. On the other hand, large quantities of irregulars may have raised the issue of control. In order to prevent these large groups from committing too many excesses, the military authorities had to find an appropriate person who could keep them disciplined. It seems that this task was entrusted to the commander of the Pandour Freikorps, Baron Trenck, famous for his heroic military endeavours, but also notorious for his harsh discipline. Several British newspapers published reports from Frankfurt and Cologne, dated June 1743, about the anticipated arrival of several thousands of "Croats, Lycanians and Pandours" under the command of Baron Trenck. ${ }^{43}$

After pushing the French forces out of Bavaria, the Austrians intended to cross the Rhine and invade the French territory. The Austrian irregulars were in charge of the first incursions across the river in order to prepare the ground for the main Austrian army. Ivan Kukuljević Sakcinski claims that in September 1743 Grenzer from Lika crossed the Rhine at Alt Breisach ${ }^{44}$ together with the Pandours. ${ }^{45}$ At the first glance, there is no evidence of their participation in the newspapers, which on many occasions mention only Baron Trenck and his Pandours. ${ }^{46}$ There are, however, a few reports which also mention Croats, Croatians or "irregulars" beside the Pandours, which suggests that there may have been Grenzer from Lika

42 The Ipswich Journal (Ipswich), online version, July 30, 1743 (OS), 3, https://www.britishnewspaperarchive.co.uk/ (last accessed on January 17, 2017).

${ }_{43}$ The Derby Mercury (Derby), online version, June 23, 1743 (OS), 2, https://www.britishnewspaperarchive.co.uk/ (last accessed on January 25, 2017); The Ipswich Journal (Ipswich), online version, June 18, 1743 (OS), 2, https://www.britishnewspaperarchive.co.uk/ (last accessed on January 16, 2017); The Ipswich Journal (Ipswich), online version, July 30, 1743 (OS), 3, https://www.britishnewspaperarchive. co.uk/ (last accessed on January 25, 2017).

${ }^{44}$ Present-day Breisach in Baden-Württemberg, Germany.

45 Kukuljević Sakcinski, Hrvati za nasljednoga rata, 36.

46 The Caledonian Mercury (Edinburgh), online version, August 23, 1743 (OS), 2, https://www.britishnewspaperarchive.co.uk/ (last accessed on November 16, 2016); The Caledonian Mercury (Edinburgh), online version, August 25, 1743 (OS), 1, https://www.britishnewspaperarchive.co.uk/ (last accessed on November 16, 2016); The Caledonian Mercury (Edinburgh), online version, August 29, 1743 (OS), 1, https://www.britishnewspaperarchive.co.uk/ (last accessed on November 16, 2016); The Derby Mercury (Derby), online version, August 18, 1743 (OS), 1-4, https://www.britishnewspaperarchive. co.uk/ (last accessed on November 16, 2016); The Newcastle Courant (Newcastle upon Tyne), online version, August 20, 1743 (OS), 2, https://www.britishnewspaperarchive.co.uk/ (last accessed on November 16, 2016); The Ipswich Journal (Ipswich), online version, August 20, 1743 (OS), https://www. britishnewspaperarchive.co.uk (last accessed on November 16, 2016). 
among these troops. ${ }^{47}$ Furthermore, since the Lycanians were previously noted under the command of Baron Trenck, it can be assumed that at least some of them participated in these endeavours with the Pandours. An article from the Wienerisches Diarium mentions specifically Liccaner, who along with a hussar regiment were supposed to cross the bridge at Seebach, ${ }^{48}$ at about a hundred kilometres' distance from Alt Breisach, where the incursion of the Pandours took place, which confirms their participation in the preparations for the passage of the rest of the Austrian army.

The newspaper articles reveal other interesting features of military life related to the Grenzer of Lika. One of them concerns their specific role during winter. In October 1743, the army of Prince Charles of Lorraine made preparations for the establishment of winter quarters in the Black Forest, while the irregular troops, including the Lycanians, were allocated closer to the Rhine. ${ }^{49}$ It can be assumed that this kind of arrangement was meant to prevent French incursions and perhaps even instigate incursions of the Austrian irregulars in the French territory. Another distinguishing feature of the Grenzer military life is the importance of the commissioner of war. This person served the important function of arranging the food supplies for the Grenzer troops. One article mentions specifically this functionary in connection with the arrival of Grenzer troops, notably Warasdiner and Liccaner. ${ }^{50}$ His duty was probably to prevent the Grenzer from plundering the local population, which seems to have been a serious problem even in the enemy territory, because of the potential French reprisals. Such an event can be witnessed in an article from The Ipswich Journal, which notes that the French threatened to continue their excesses in Luxembourg as reprisals for the violence committed by the Austrian irregulars in Alsace and Lorraine. ${ }^{51}$

\footnotetext{
47 The Caledonian Mercury (Edinburgh), online version, August 25, 1743 (OS), https://www.britishnewspaperarchive.co.uk (last accessed on November 16, 2016); The Derby Mercury (Derby), online version, August 11, 1743 (OS), https://www.britishnewspaperarchive.co.uk (last accessed on November 16, 2016); The Newcastle Courant (Newcastle upon Tyne), online version, August 13, 1743 (OS), https://www.britishnewspaperarchive.co.uk (last accessed on November 16, 2016).

48 Seebach is another term for Zürich, but it is not likely that it refers to this place. There are two other possibilities. One is a town in the Bas-Rhin department of Grand Est in north-eastern France and the other a town in Baden-Württemberg. They are located close to each other and not far from Cologne or Frankfurt, where the presence of Grenzer from Lika is noted.

49 The Newcastle Courant (Newcastle upon Tyne), online version, October 15, 1743 (OS), 2, https:// www.britishnewspaperarchive.co.uk/ (last accessed on February 8, 2017).

50 Wienerisches Diarium (Vienna), online version, November 6, 1743, 13, http://anno.onb.ac.at/ (last accessed on March 6, 2017).

51 The Ipswich Journal (Ipswich), online version, October 8, 1743 (OS), 1, https://www.britishnewspaperarchive.co.uk/ (last accessed on February 8, 2017).
} 


\section{The Italian theatre of war $(1744-1747)$}

A fairly large number of newspaper articles covered the exploits of the Lycanians during the Habsburg campaigns against the Spanish and Neapolitan forces on the Apennine Peninsula. In the late spring of 1744, the Lycanians were marching towards Rome in order to join the rest of the Austrian army under the command of Prince Lobkowitz. However, it seems that difficulties arose because the Spanish and Neapolitans troops were laying waste the Romagna region in order to deprive the Austrians of the necessary provisions. ${ }^{52}$ Luckily enough, the Pope furnished the Lycanians and other Austrian troops with necessities, probably trying to prevent the irregulars from plundering the region. A letter from Prince Lobkowitz, dated June 13,1744, informs that "as a considerable Body of Lycanians had join'd the Austrians, they were in Hopes of being soon able to undertake the Dislodging the Spaniards and Neapolitans, who had fortified themselves as much as possible in and about Velletri..." 53

From June through August, the area around Velletri was the main point of military manoeuvring between the two armies. In the two battles that took place, both of them bearing the name of this ancient town, although the first one was also known as the battle of Nemi, the Grenzer from Lika took part. ${ }^{54}$ According to a report from Rome, just after joining Prince Lobkowitz's army, on June 16 a detachment of Licanians captured two Spanish posts and were reinforced there by the Sclavonians. However, what followed may be linked to the claim by Gunther Eric Rothenberg that one of the main problems concerning the Grenzer troops were the difficulties with which their officers struggled to uphold discipline. The Grenzer were prone to drunkenness and plunder, even when they were situated in friendly areas. ${ }^{55} \mathrm{On}$ this occasion, they found large quantities of wine left behind by the Spanish and decided to drink it as part of the celebration for their recent accomplishment. The Spanish commander, Count Gages, had anticipated that the Grenzer would get drunk and sent large numbers of irregulars, the Miquelets, ${ }^{56}$ as well as regular troops to retake the posts. Prince Lobkowitz also sent reinforcements to aid the Grenzer, but the whole affair had

\footnotetext{
52 The Derby Mercury (Derby), online version, June 15, 1744 (OS), 2, https://www.britishnewspaperarchive.co.uk/ (last accessed on January 17, 2017).

53 The Derby Mercury (Derby), online version, June 29, 1744 (OS), 2, https://www.britishnewspaperarchive.co.uk/ (last accessed on January 17, 2017).

54 For more information about the battles, see Browning, The War of the Austrian Succession, 163-166.

55 Rothenberg, The Military Border, 20.

${ }^{56}$ Miquelets were irregular forces hired by the Spanish crown. They were actually armed peasants who lived in their own culture of violence, which contradicted the concept of the state monopolization of violence. Like the Grenzer, they were fierce warriors, but difficult to control. Cf. Starkey, War in the Age of Enlightenment, 136.
} 
disastrous consequences for the Austrians. About 400 men died and 600 were made prisoners. ${ }^{57}$

After this shameful event, the Lycanians had a chance to redeem themselves during the second battle of Velletri, which took place on August 12, 1744. The main objective was an attempt to capture the Neapolitan ruler Charles VII ${ }^{58}$ who had just arrived at Velletri. A corps of 6000 men under the command of Count Maximilian Ulysses von Browne (1705-1757) was assigned the task of executing this surprise mission. ${ }^{59}$ According to the newspapers, the Lycanians were among these troops. They surprised and defeated three Spanish cavalry regiments located in front of the town and then overpowered four infantry regiments inside the town. Even though they successfully participated in the execution of this swift attack, taking the enemy by surprise, once inside the town walls the Grenzer started killing everyone they encountered. ${ }^{60}$ Browning also notes that Browne's troops started looting and drinking upon entering the city, but he does not specifically mention the Grenzer, rather Austrians in general. Either way, the king managed to escape and regroup his forces outside the city for a counterattack. Unable to take charge of his men and not receiving the expected reinforcements, Browne decided to retreat. ${ }^{61}$ These accounts suggest that discipline presented a crucial issue with the Grenzer, in this case those from Lika, but also with the Austrian troops in general. Newspaper reports place the blame solely on the Grenzer, but perhaps insubordination and self-will were not inherent only to them, but a common occurrence among the Austrian soldiers before the introduction of the Theresian military reforms.

Nonetheless, the Lycanians continued to serve their purpose by performing many demanding tasks during the retreat of the Austrian army northwards, following the defeat at Velletri. For instance, according to the reports from Rome and Pe-

\footnotetext{
57 The Newcastle Courant (Newcastle upon Tyne), online version, July 7, 1744, 2, https://www.britishnewspaperarchive.co.uk/ (last accessed on January 17, 2017). Another article in the same newspaper, on the same page, informs that about 500 were killed or taken prisoner and that the hussars and Croatians posted there got drunk, but "through the Inattention of their Commander." Because of bad printing, it is not possible to distinguish the post from which the report had come. Browning mentions that the men guarding these advanced posts were asleep and that their commander was visiting a winery. He also notes that, in general, the Austrian soldiers encamped around Rome were entangled in various forms of leisure activity. Browning, The War of the Austrian Succession, 163-164. Thus, the blame should perhaps not be placed on the Grenzer alone, but on the lack of discipline which had engulfed the entire Austrian army.

58 From 1734 he ruled the Kingdom of Naples as Charles VII and the Kingdom of Sicily as Charles V until 1759, when he inherited the Spanish crown as Charles III (1759-1788).

59 Browning, The War of the Austrian Succession, 164.

60 The Derby Mercury (Derby), online version, July 6, 1744 (OS), 3, https://www.britishnewspaperarchive.co.uk/ (last accessed on January 17, 2017); Wienerisches Diarium (Vienna), online version, September 9, 1744, 20, http://anno.onb.ac.at/ (last accessed on March 6, 2017).
}

${ }_{61}$ Browning, The War of the Austrian Succession, 165. 
rugia dated October 1744, the Grenzer from Lika and Slavonia were assigned the task of slowing down the advance of the Spanish forces over the river Tiber near the city of Rome. ${ }^{62}$ It is important to emphasize the fact that they did not only assume defensive positions, but also launched furious surprise attacks on the Spanish, which enabled the withdrawal of the precious, but slow-moving Austrian artillery. ${ }^{63}$ These actions enabled the Austrian army to retreat to Viterbo, north of Rome, but they did not come without cost. A report from Rome informs that the Miquelets captured 35 Licanians, ${ }^{64}$ which suggests that the Grenzer had difficulties when they encountered their Spanish counterparts.

The Grenzer of Lika not only formed the rearguard of the Austrian army, but were also charged, due to their mobility, with the task of moving ahead of the army and preventing the Spanish forces from cutting its retreat to the north. This was the case in November 1744 when, upon learning that the enemy was in full march towards Foligno, the Grenzer forces, including the Esclavans and Lycanians, were sent along with the cavalry from Orvieto northwards to Città della Pieve.$^{65}$ Even when winter was approaching, the Lycanians did not find peace, for when the winter quarters of the Austrian army were set up, the Grenzer of Lika were positioned along the line from Fano to Urbino, facing the anticipated position of the Spanish winter quarters along the line from Perugia to the Marche region. ${ }^{6}$ It is possible to draw a parallel with establishing the Austrian winter quarters in the Rhineland a year earlier.

Performing all these various tasks must have been overburdening for the Grenzer of Lika. Possible evidence to support this claim can be found in a report from Florence dated January 26, 1745, when a group of "800 Lycanians and Sclavonians" from Cesena attempted to return to their homeland. Ultimately, they were persuaded to stay by their officers. ${ }^{67}$ During the rest of the year, the Lycanians

62 The Caledonian Mercury (Edinburgh), online version, November 27, 1744, 1, https://www.britishnewspaperarchive.co.uk/ (last accessed on January 18, 2017); The Derby Mercury (Derby), online version, November 23, 1744 (OS), 1, https://www.britishnewspaperarchive.co.uk/ (last accessed on January 18, 2017); The Newcastle Courant (Newcastle upon Tyne), online version, November 24, 1744 (OS), 1, https://www.britishnewspaperarchive.co.uk/ (last accessed on January 18, 2017); Wienerisches Diarium (Vienna), online version, December 14, 1744 (OS), 2, http://anno.onb.ac.at/ (last accessed on March 9, 2017).

${ }^{63}$ The Caledonian Mercury (Edinburgh), online version, December 3, 1744 (OS), 1, https://www.britishnewspaperarchive.co.uk/ (last accessed on January 18, 2017).

${ }^{64}$ The Stamford Mercury (Stamford), online version, December 6, 1744 (OS), 1, https://www.britishnewspaperarchive.co.uk/ (last accessed on January 26, 2017).

65 The Caledonian Mercury (Edinburgh), online version, December 17, 1744 (OS), 1, https://www. britishnewspaperarchive.co.uk/ (last accessed on January 26, 2017).

${ }^{66}$ Wienerisches Diarium (Vienna), online version, December 26, 1744, 2, http://anno.onb.ac.at/ (last accessed on March 6, 2017).

${ }_{67}$ The Caledonian Mercury (Edinburgh), online version, February 18, 1745 (OS), 1, https://www.britishnewspaperarchive.co.uk/ (last accessed on January 26, 2017); The Newcastle Courant (Newcastle 
continued to perform various military tasks suited for light infantry. In spring, they were monitoring the motions of the Spanish army, which was attempting to cross the river Panaro in the Modena region. ${ }^{68}$ However, it seems that the Grenzer of Lika, or at least a part of their corps, were also employed elsewhere on the Apennine Peninsula. They were present in the Kingdom of Piedmont-Sardinia as well, probably with the task of slowing down the enemy forces advancing from France. ${ }^{69}$ An article from the Newcastle Courant reports on the exceptional bravery of a small force of "Licanians and Hussars" stationed at Vignolo in Piedmont, "who defended themselves against the enemy with all bravery imaginable." The small force did not retreat until it ran out of ammunition and provisions. ${ }^{70} \mathrm{An}$ other report from Zola near Bologna informs that on May 29, the Liccaner Corpo returned to the army. ${ }^{71}$ In June, a report from Turin indicates them, along with the Pandours, as part of the garrison of the city of Novi, in the territory of the Republic of Genoa. ${ }^{72}$ It seems that the Grenzer of Lika were either divided in the Italian theatre of war or quickly deployed on various battlegrounds because of their rapid mobility.

After signing the treaty of Dresden on Christmas 1745, which excluded Prussia from the war for the second time, the Habsburg Monarchy devoted its maximum efforts to the Italian theatre of war. In the spring of 1746, British newspapers inform that the best parts of the Grenzer forces were being sent to Italy. ${ }^{73}$ Ivan Jurišić claims that in 1746, because of a rebellion in parts of the Lika and Otočac Regiments, the Grenzer from these parts of the Karlstadt Generalate did not partake in the military campaigns. ${ }^{74}$ However, the newspaper articles call this claim

upon Tyne), online version, February 9, 1745 (OS), 2, https://www.britishnewspaperarchive.co.uk/ (last accessed on January 26, 2017).

68 The Derby Mercury (Derby), online version, April 26, 1745 (OS), 3, https://www.britishnewspaperarchive.co.uk/ (last accessed on January 19, 2017); The Newcastle Courant (Newcastle upon Tyne), online version, April 27, 1745 (OS), 1, https://www.britishnewspaperarchive.co.uk/ (last accessed on January 19, 2017); Wienerisches Diarium (Vienna), online version, May 1, 1745, 3, http://anno.onb. ac.at/ (last accessed on March 9, 2017).

69 Already in August 1744, Maria Theresia dispatched 3,000 Croats from Lombardy to aid the king of Sardinia, Charles Emmanuel III (1730-1773), against the Bourbon forces which invaded Piedmont. Browning, The War of the Austrian Succession, 186.

70 The Newcastle Courant (Newcastle upon Tyne), online version, May 4, 1745 (OS), 1, https://www. britishnewspaperarchive.co.uk/ (last accessed on January 26, 2017).

71 Wienerisches Diarium (Vienna), online version, June 26, 1745, 1, http://anno.onb.ac.at/ (last accessed on March 9, 2017).

72 Wienerisches Diarium (Vienna), online version, July 7, 1745, 2, http://anno.onb.ac.at/ (last accessed on March 9, 2017).

73 The Stamford Mercury (Stamford), online version, April 17, 1746 (OS), 1, https://www.britishnewspaperarchive.co.uk/ (last accessed on February 10, 2017).

${ }^{74}$ According to Jurišić, at the end of July 1746, only the troops from the Slunj and Ogulin Regiments were dispatched to the Italian and Dutch battlefronts. Jurišić, Karlovački generalat, 191. 
into question. For instance, we can find evidence in the Wienerisches Diarium from May 1746 that the Grenzer of Lika, or at least a part of their corps, were called back from the territory of the Republic of Genoa and dispatched to Pontremoli and Aulla, located in Tuscany, in order to enlarge the Imperial troops. ${ }^{75}$ Since the rebellion brook out at the end of July, these could have been the Grenzer from Lika who had remained on the Italian battlefront from the last campaign season, and were not part of the fresh new troops dispatched from the Karlstadt Generalate at the time the rebellion broke out. On the other hand, the necessity for fresh, new, and reformed Lycanians was also present. A report from Vienna dated November 12, informed that Prince Hildburghausen was speedily returning to Croatia in order to prepare "one half of his fine regiment of Lycanians" for a march towards the Apennine Peninsula, which was awarded the main focus in the current war. ${ }^{76}$ However, these praiseworthy Grenzer were actually designated for another theatre of war, as will soon be examined.

The Grenzer of Lika, present in the Italian theatre of war in 1746, performed an important military function during the offensive that the joined Austrian and Piedmont forces launched in the direction of Provence late in 1746. At the end of November, the army intended to pass the river Var, which marked the border between Piedmont and Provence. According to an article from Wienerisches Diarium, 400 Liccaner, posted at Villafranca Piemonte, participated in the endeavour of crossing the river first. ${ }^{77}$ British newspapers mention the participation of other Grenzer or Croatians beside the Lycanians, as well as grenadiers and hussars. Based on a detailed description, we learn that after crossing the river, they executed a flank attack on a strong French redoubt posted at the village of St Laurent, forcing the enemy to flee and making it possible for the army under Feldzeugmeister Browne to cross the river. ${ }^{78}$

In 1747, the Grenzer of Lika participated in quelling an uprising of the Genoese who had rebelled against the Habsburg occupation. In April, their strength was

75 Wienerisches Diarium (Vienna), online version, May 18, 1746, 3, http://anno.onb.ac.at/ (last accessed on March 9, 2017).

${ }^{76}$ The Caledonian Mercury (Edinburgh), online version, November 24, 1746 (OS), 2, https://www. britishnewspaperarchive.co.uk/ (last accessed on January 19, 2017).

77 Wienerisches Diarium (Vienna), online version, December 14, 1746, 1, http://anno.onb.ac.at/ (last accessed on March 9, 2017).

78 The Caledonian Mercury (Edinburgh), online version, December 11, 1746 (OS), 1, https://www. britishnewspaperarchive.co.uk/ (last accessed on January 19, 2017); The Derby Mercury (Derby), online version, December 5, 1746 (OS), 3, https://www.britishnewspaperarchive.co.uk/ (last accessed on January 19, 2017); The Newcastle Courant (Newcastle upon Tyne), online version, December 6, 1746 (OS), 2, https://www.britishnewspaperarchive.co.uk/ (last accessed on January 19, 2017); The Scots Magazine (Edinburgh), online version, December 5, 1746 (OS), 36, https://www.britishnewspaperarchive.co.uk/ (last accessed on January 19, 2017); The Stamford Mercury (Stamford), online version, December 11, 1746 (OS), 2, https://www.britishnewspaperarchive.co.uk/ (last accessed on January 19, 2017). 
needed in order to get the Austrian cannons onto the hills, since the Genoese rebels had spoiled the roads. ${ }^{79}$ In May, a reinforcement of 1500 Lycanians was marching towards Genoa. ${ }^{80}$ The skills of the Grenzer, adapted to guerrilla-style warfare, must have been very useful in fighting the Genoese rebels as the latter were using similar tactics. However, there was a negative side to this irregular warfare. According to a journal report by an anonymous traveller who had crossed the area between April and July, the Genoese villages were in a miserable state. The destruction which he witnessed there revealed the savagery of the "Croats, Warasdins, \&c." ${ }^{81}$ Even though the Lycanians are not mentioned specifically, we can presume that they may be hiding behind the term Croats, since their presence in that area was previously confirmed. The last report concerning the presence of the Lycanians in the Apennine Peninsula dates from the last year of war. According to a report from Milan in June, a total of 2,700 irregulars, including the Lycanians, were expected to arrive soon. ${ }^{82}$

\section{Lycanians in the Low Countries}

The contemporary newspapers recorded the presence of Grenzer from Lika at another battlefront, namely, the Austrian Netherlands, where the French were trying to dislodge the Austrians and their British and Dutch allies. In 1746, there is no mention of the presence of Grenzer from Lika, possibly because they were engaged in the Italian theatre of war, or perhaps because that year a revolt broke out in the Karlstadt Generalate as a result of the military reform, as described earlier. The first news regarding the Grenzer troops in the Low Countries is related to a report from Breda, dated May 23, 1746, which describes the difficulties associated with the arrival of the Austrian irregular forces, including the "Hussars, Croats and Pandours." The terrible appearance of these troops caused fear and insecurity among the enemy forces, as well as the local peasantry. The report also highlights the great efforts of the Croatian Ban and Austrian Feldmarschall Charles Joseph Count Batthyány (1697-1772) to uphold the discipline among these men. This main issue was supplying them with the necessary provisions, which was to be solved with the help of the grand magazine located at Breda. ${ }^{83}$

\footnotetext{
79 The Derby Mercury (Derby), online version, April 3, 1747 (OS), 3, https://www.britishnewspaperarchive.co.uk/ (last accessed on January 19, 2017).

80 The Caledonian Mercury (Edinburgh), online version, June 1, 1747 (OS), 2, https://www.britishnewspaperarchive.co.uk/ (last accessed on January 20, 2017).

81 The Derby Mercury (Derby), online version, September 4, 1747 (OS), 3, https://www.britishnewspaperarchive.co.uk/ (last accessed on February 10, 2017).

82 The Aberdeen Press and Journal (Aberdeen), online version, July 19, 1748 (OS), 2, https://www. britishnewspaperarchive.co.uk/ (last accessed on January 23, 2017).

83 The Stamford Mercury (Stamford), online version, May 29, 1746 (OS), 1, https://www.britishnewspaperarchive.co.uk/ (last accessed on February 10, 2017).
} 
This report reveals the problems that the Austrian military authorities had to face upon the completion of the equalling process between the Grenzer and the other, regular soldiers in the Austrian army. The example of the Pandours, who had attained the status of regular soldiers the previous year, ${ }^{84}$ but seem to have continued enjoying the "privileges" of the irregulars, suggests that the implementation of these changes may not have taken effect so swiftly. Perhaps the Austrian military authorities were not prepared, in the logistical sense, for supplying an increased number of soldiers with provisions. Moreover, these men may have simply been reluctant to give up their old right to plunder.

On January 6, 1747 the commander of the Karlstadt Generalate, General Major Lepold Scherzer, issued an order by which two battalions of the Lika Regiment were supposed to depart for the Duchy of Brabant in the Austrian Netherlands. ${ }^{85}$ In spring, several British newspapers published accounts which testify to the presence of Lycanians in the mentioned region. The article stipulates that they were part of a large Austrian force that was foraging the area, much to the displeasure of the local populace. Their role seems to have involved skirmishing with the French light infantry troops that they occasionally encountered. On the last day of May, they discovered a strong advanced French post at Aerschot, which they successfully captured with some losses. With the help of the hussars, they also confronted French light infantry at Schrick and drove them away. ${ }^{86}$

Although work on the reform of the Warasdin and Karlstadt Generalates was completed, in case of the former in 1745 and the latter in 1746, it was not until the end of April 1747 that Maria Theresia equated them with the other regular regiments in the Austrian army. ${ }^{87}$ The Grenzer of Lika nevertheless continued to be employed as skirmishers in the Low Countries. A possible explanation may be deduced from the fact that around this time an increasing number of light troops is recorded among the French troops. In order to counter this threat, the importance of Grenzer troops was vital. The Lycanians were particularly busy

${ }_{84}$ By the decree of Maria Theresia from March 17, 1745, Trenck's Pandour Freikorps was awarded the status of a regular infantry regiment. For additional details, see Alexander Buczynski, "Uspon i pad pandurskog pukovnika Franje baruna Trenka," in: Memoari baruna Franje Trencka, ed. Alexnder Buczynski, Milan Vrbanus and Mica Orban Kljajić (Slavonski Brod: Hrvatski institut za povijest, Podružnica za povijest Slavonije, Srijema i Baranje, 2015), 14, 19-20.

${ }^{85}$ Franz Bach, Povijest Otočke pukovnije: o nastanku ovoga kraja, njegovim žiteljima i njihovim sudbinama, trans. Manuela Svoboda, ed. Milan Kranjčević (Zagreb: Hrvatski institut za povijest; Otočac: Katedra Čakavskog sabora pokrajine Gacke, 2010), 105.

86 The Derby Mercury (Derby), online version, May 22, 1747, 4, https://www.britishnewspaperarchive. co.uk/ (last accessed on January 23, 2017); The Newcastle Courant (Newcastle upon Tyne), online version, May 23, 1747 (OS), 3, https://www.britishnewspaperarchive.co.uk/ (last accessed on January 20, 2017); The Ipswich Journal (Ipswich), online version, May 30, 1747, 2, https://www.britishnewspaperarchive.co.uk/ (last accessed on January 20, 2017).

87 Jurišić, Karlovački generalat, 159-160. 
performing military tasks suitable for light infantry troops in June 1747. These tasks included defending advanced posts, performing surprise attacks or ambushes against the French troops, and defending the rear of the allied army. Detailed examples of all the listed tasks can be found in the British newspapers. For instance, on June 16, a French force under the command of Lieutenant General Comte de St. Germain, intended to capture the allied posts and thus clear the route to Maastricht. One of such posts was Diest, where several hundred "irregulars" under the command of Major Beck ${ }^{88}$ successfully defended themselves until reinforcements came to their aid, compelling the French to retreat. The following morning, the Grenzer from Lika, with the support of regular troops, attacked the French rearguard, causing commotion and forcing them to abandon their posts along the river Demer. ${ }^{89}$

These sort of surprise attacks had a significant importance as they caused alarm among the enemy forces and incited them to change their motions. Surprise attacks were also used as reprisals for French actions. For instance, one report describes that several hundred French volunteers were assigned the task of crossing the river Dyle and preparing ambushes for the allied patrols. As a reprisal for these acts, the Austrian commander, General Trips, dispatched 1000 light infantrymen and 400 hussars under the command of Major General Calnoky, with the task of drawing out the French troops and luring them into an ambush. In this event, which took place near the convent of Rosendhal in the Austrian Netherlands, the Lycanians and the Pandours are mentioned among the participants. The tactic consisted of feigning an attack, which was probably performed by the Grenzer, and provoking the French into pursuing them with fixed bayonets. The runaways then led the French into an ambush, where the rest of the infantrymen fired a salvo, supported by the Pandour grenadiers and a flank attack by the hussars. The article highlights the success of the Austrian side by noting that the enemy loses included 200 dead and 20 wounded, while the Austrian side had only seven dead, including one Lycanian, and 20 wounded..$^{90}$ This example proves

\footnotetext{
${ }_{88}$ According to Kukuljević Sakcinski, these "irregulars" were four companies of the Lika Regiment and a company of Pandours. However, Beck may have not been the major of the Lika Regiment, since Kukuljević Sakcinski does not include him in the list of officers of that regiment who participated in the campaign of 1747-1748. Cf. Kukuljević Sakcinski, Hrvati za nasljednoga rata, 85-86.

89 The Caledonian Mercury (Edinburgh), online version, June 18, 1747 (OS), 1, 3, https://www.britishnewspaperarchive.co.uk/ (last accessed on January 20, 2017); The Derby Mercury (Derby), online version, June 12, 1747 (OS), 3, https://www.britishnewspaperarchive.co.uk/ (last accessed on January 20, 2017); Newcastle Courant (Newcastle upon Tyne), online version, June 13, 1747 (OS), 2, 3, https:// www.britishnewspaperarchive.co.uk/ (last accessed on January 22, 2017); The Scots Magazine (Edinburgh), online version, June 5, 1747 (OS), 32-33, https://www.britishnewspaperarchive.co.uk/ (last accessed on January 31, 2017).

90 The Caledonian Mercury (Edinburgh), online version, June 18, 1747 (OS), 1, https://www.britishnewspaperarchive.co.uk/ (last accessed on January 22, 2017); The Derby Mercury (Derby), online version, June 12, 1747 (OS), 3, 4, https://www.britishnewspaperarchive.co.uk/ (last accessed on January
} 
once again the effectiveness of a combined action of light (Lycanian) Grenzer troops, elite grenadiers, and light (hussar) cavalry.

On 24 June, the allied army marched off towards Maastricht, one of the most formidable fortresses in the Low Countries, which was the goal of the French army under Marshal Maurice de Saxe. ${ }^{91}$ About 300 Lycanians and Pandours from General Trips' rearguard were left at Lier, probably with the task of slowing down the advance of the French. The French surrounded them and demanded that they capitulate. However, the brave defenders refused the offer and stormed out of the town, cut their way through with minor losses, and joined General Trips' forces. ${ }^{92}$

The significance of the Lycanian Grenzer was also acknowledged during major battles. Such a battle occurred at the beginning of July 1747 . The battle took place near the village of Lauffeld, from which it got the name, although it is sometimes also referred to as The Battle of Maastricht or Val. Under the latter term it was described in the British newspapers. Although the date of the battle is officially July 2 , the skirmishing, dominated by the light troops on both sides, started already a day earlier. ${ }^{93}$ Around six in the afternoon on July 1 , the skirmishing between the French irregulars on one side, and the hussars and Lycanians on the other, began. At the same time, the French cavalry was trying to occupy the heights of the Herderen hill. All of this was done to conceal the march of the infantry, which kept moving to the left of the allied army.

The assignment of covering that wing of the army was entrusted to General Trips and his light infantrymen, who had just arrived after covering the march of the army from Lier. ${ }^{94}$ They were in charge of monitoring the motion of the French army towards the river Meuse, because it was suspected that the French were intending to cut the allied army from Maastricht. The newspapers end the report by acknowledging that the allies had suffered a defeat in the battle, but that

22, 2017); The Newcastle Courant (Newcastle upon Tyne), online version, June 13, 1747 (OS), 2, 3, https://www.britishnewspaperarchive.co.uk/ (last accessed on January 21, 2017).

${ }_{91}$ For more details about the French plan of capturing Maastricht, see Browning, The War of the Austrian Succession, 313-316.

92 The Caledonian Mercury (Edinburgh), online version, July 2, 1747 (OS), 1, https://www.britishnewspaperarchive.co.uk/ (last accessed on January 23, 2017); The Derby Mercury (Derby), online version, June 26, 1747 (OS), 3, https://www.britishnewspaperarchive.co.uk/ (last accessed on January 23, 2017); The Newcastle Courant (Newcastle upon Tyne), June 27, 1747 (OS), 1, https://www.britishnewspaperarchive.co.uk/ (last accessed on January 23, 2017); The Scots Magazine (Edinburgh), online version, June 5, 1747 (OS), 32-33, https://www.britishnewspaperarchive.co.uk/ (last accessed on January 31, 2017).

93 As Duffy explains, most battles that the Austrians waged during the reign of Maria Theresia started in this manner. The light troops of both sides were the first ones to exchange fire. This was followed by heavy artillery. Cf. Duffy, The Army of Maria Theresa, 142.

94 The Lycanians may also have been part of this force, since they are mentioned earlier as part of the rearguard under General Trips. 
the enemy suffered much more casualties. ${ }^{95}$ The battle was lost for the allies and blame could be placed on the Grenzer for not fulfilling their task, but also on the commanders for not duly strengthening that part of the army. Leaving the causes of the defeat aside, this account testifies to the importance of Grenzer and other light infantry forces in the military actions preceding the battle. These actions were vital for concealing the true alignment of forces and made it possible for the army to form lines or perform any other manoeuvre that was an integral part of every battle. The alignment of troops at the suitable moment was crucial for attaining victory. This example also testifies to the fact that the Lycanians were among the first and the last to engage the enemy, which made their participation crucial and probably inflicted many casualties.

Three more reports from summer 1747 mention the Lycanians. The first one informs that late in July they fortified themselves inside Maaseik, located on the left bank of the river Meuse, bordering the United Provinces. The article refers to them as Croaten, but since Obrist Guicciardi is mentioned as their commander, it is possible to presume that they were in fact Grenzer from Lika. ${ }^{96}$ Shortly afterwards, they seem to have crossed into the Dutch territory, since their presence is recorded in Breda in August and in the village of Wouw in September. ${ }^{97}$ The reports do not reveal which tasks the Grenzer performed there, but we can assume that it was probably skirmishing with the French light troops.

\section{Assessing the Lycanians}

Impressions regarding the Grenzer generally varied. For instance, Prince Hildburghausen regarded them as efficient and strong soldiers, of better quality than the German infantrymen, but lacking discipline. He viewed the Military Frontier as a valuable source of wealth, since it could provide numerous soldiers of high quality to the Habsburg Monarchy. ${ }^{98}$ In contrast, Count Browne, under whose command the Lycanians served in Italy, allegedly harboured great disdain for the

95 The Caledonian Mercury (Edinburgh), online version, July 7, 1747 (OS), 1, https://www.britishnewspaperarchive.co.uk/ (last accessed on January 23, 2017); The Derby Mercury (Derby), online version, July 3, 1747 (OS), 1, 2, https://www.britishnewspaperarchive.co.uk/ (last accessed on January 23, 2017); The Scots Magazine (Edinburgh), online version, June 5, 1747 (OS), 33-35, 37, https://www. britishnewspaperarchive.co.uk/ (last accessed on January 31, 2017).

96 Wienerisches Diarium (Vienna), online version, August 12, 1747, 5, http://anno.onb.ac.at/ (last accessed on January 11, 2017).

${ }_{97}$ The Derby Mercury (Derby), online version, August 7, 1747 (OS), 2, https://www.britishnewspaperarchive.co.uk/ (last accessed on January 23, 2017); The Derby Mercury (Derby), online version, September 25, 1747 (OS), 1, https://www.britishnewspaperarchive.co.uk/ (last accessed on January 23, 2017); The Newcastle Courant (Newcastle upon Tyne), online version, September 26, 1747 (OS), 1, https://www.britishnewspaperarchive.co.uk/ (last accessed on January 22, 2017).

98 Jurišić, Karlovački generalat, 71; Rothenberg, The Austrian Military Border, 114-115. 
Grenzer troops. He disapproved of Hildburghausen's attempt at reforming the Military Frontier and of his affinity towards the Grenzer. ${ }^{99}$ Some of the reasons may be in his experience with the Lycanians during the Italian campaign and the unsuccessful battles at Velletri.

Obviously, these officers of high rank had their reasons for liking or disliking the Grenzer. But what was the opinion of the British? The newspaper articles offer several reports which describe the attitude towards these types of soldiers, including the Lycanians. For instance, words of praise for the irregulars fighting in the Austrian army can be found in an article dated August 3, 1744 from The Caledonian Mercury. The article reveals a somewhat incredible idea concerning the continuation of the military endeavours. According to this plan, the maritime powers, the British and the Dutch, would focus all their efforts on naval warfare, while their armies would we disbanded. They would, however, send subsidies to Vienna in order for the Grenzer and other irregular forces from the Habsburg domains to be recruited and sent to the French provinces. Among these irregulars, specifically the Lycadians are mentioned. ${ }^{100}$ Although the plan itself was unrealistic, it does demonstrate the high regard of the British for the Grenzer from Lika and other parts of the Military Frontier.

A similar report can be found in an article published the following year in The Scots Magazine. The article informs on the proceedings of a certain political club, which debated over the question whether it was necessary to send military aid to the Austrian forces in Bohemia. The conclusion was that there was no need for such a move, because the Queen of Hungary had "Her Croats, Pandours, Lycanians, Hussars, and other troops with hard names, and constitutions as hard as their names... all bred up upon the borders of Turky, and accustomed to arms from their infancy." 101

As it was mentioned earlier, in 1746 the Lycanian Grenzer acquired the status of regular soldiers and as such were subject to stricter rules concerning discipline. This transformation was acknowledged by the newspapers as well, as a report from Vienna dated February 22 that same year demonstrates. It informs that the second battalion of the Lycanian regiment, which was designated to travel to the Low Countries, arrived in Vienna. What is peculiar is the fact that these 1000 men arrived under the command of Prince Hildburghausen, "who has raised and disciplined them." 102 This suggests that the process of transformation of

\footnotetext{
${ }_{99}$ Jurišić, Karlovački generalat, 238, n. 52.

100 The Caledonian Mercury (Edinburgh), online version, July 23, 1744 (OS), 2, https://www.britishnewspaperarchive.co.uk/ (last accessed on February 7, 2017).

${ }^{101}$ The Scots Magazine (Edinburgh), online version, January 4, 1745 (OS), 21, https://www.britishnewspaperarchive.co.uk/ (last accessed on January 18, 2017).

${ }^{102}$ The Derby Mercury (Derby), online version, February 27, 1746 (OS), 3, https://www.britishnewspaperarchive.co.uk/ (last accessed on January 19, 2017).
} 
the Grenzer into a regular infantry regiment had already taken place, although according to Ivan Jurišić the process was not officially finished before summer 1746. Another article describing the same event, notes that on February 12, the royal majesties reviewed this regiment, which was to serve as an escort for the wagons carrying gifts for the commander of the British forces, Prince William, Duke of Cumberland (1721-1765). ${ }^{103}$ This second report also suggests that the Lycanians were not only being regarded as disciplined soldiers, but that they were also awarded the honourable task of escorting gifts for such a dignitary.

News concerning the change in the status of the Grenzer from Lika continued to fill the pages of British newspapers in 1747. According to a report from Vienna published at the end of winter noted that the whole Lycanian regiment, containing six battalions, was on the march towards the Low Countries and that all of these six thousand men were uniformed. ${ }^{104}$ This article emphasizes the fact that the reform process was successfully concluded, since the Lycanians were no longer regarded as irregulars, but as a "regiment" of regular soldiers. On the other hand, it also highlights the efforts of the central authorities to provide these new soldiers with appropriate garments so that they could perform their duties with less hardship, which was in accordance with the previously mentioned military reforms of Maria Theresia.

Even after the War of the Austrian Succession had ended, British newspapers did not cease to shower the Lycanians with words of praise. In 1752, newspaper articles confirmed the fact that they had proved themselves as disciplined soldiers and thus completed the transformation envisaged by Prince Hildburghausen. The articles also mention that the Lycanians and other Grenzer comprised one third of the forces at the disposal of Maria Theresia. ${ }^{105}$ This figure may be lightly exaggerated, but it nonetheless shows that the Grenzer were considered as valuable combatants in the service of the Habsburg ruler. In 1754, when the Austrian army was practicing its manoeuvres in the camp of Kolin in Bohemia, a report from Vienna described "Scherzer's Regiment of Lycanians" with the epithet "fine." The exceptional height of these 6000 men was also mentioned, which

\footnotetext{
${ }^{103}$ The Stamford Mercury (Stamford), online version, March 5, 1746 (OS), 1, https://www.britishnewspaperarchive.co.uk/ (last accessed on January 19, 2017); Stamford Mercury (Stamford), online version, March 5, 1747 (OS), 1, https://www.britishnewspaperarchive.co.uk/ (last accessed on January 19, 2017).

${ }^{104}$ The Caledonian Mercury (Edinburgh), online version, March 6, 1747 (OS), 2, https://www.britishnewspaperarchive.co.uk/ (last accessed on January 19, 2017).

105 The troops counted 95,000 men in total, and "the Lycanians, Croates, Bannalisters, \&c." 65,000 more. The Aberdeen Press and Journal (Aberdeen), online version, December 26, 1752, 3, https://www. britishnewspaperarchive.co.uk/ (last accessed on January 23, 2017); The Derby Mercury (Derby), online version, December 22, 1752, 3, https://www.britishnewspaperarchive.co.uk/ (last accessed on January 23,2017$)$.
} 
amounted to five feet and eight inches in case of the shortest and six feet and some inches in case of the tallest men. ${ }^{106}$

\section{Conclusion}

From the time when Lika and Krbava became parts of the Habsburg Monarchy at the end of the $17^{\text {th }}$ century, the inhabitants of these regions displayed a significant degree of defiance and self-will, which made them unpopular with the authorities in charge of governing the area. Throughout the first half of the $18^{\text {th }}$ century, the locals managed to safeguard their privileges and persistently opposed the introduction of any changes. Upon the ascension of Maria Theresia to the throne, the Habsburg armed forces were not completely up to the challenge of facing multiple enemies on various battlefronts. Therefore, the sovereign of the vast Habsburg domains rallied all the troops at her disposal, regardless of their reputation as subjects. During the course of the War of the Austrian Succession, weaknesses were detected among the various Austrian troops and these shortcomings were addressed by way of military reforms. In case of the Grenzer, the reform of the Military Frontier affected their status in that by the end of the war they would be equalled in status with the regular troops in the Austrian army. However, regardless of their status, they continued to be employed as light infantry troops.

Observing the military endeavours of the Grenzer from Lika during the afore-mentioned conflict, it is possible to identify some of their distinguishing features. For instance, throughout the course of the war they were deployed in various theatres of war, such as Bohemia, Bavaria, the Rhineland, Alsace, Central Italy, Piedmont, Liguria, Provence, and the Low Countries. No matter where they were located, the Lycanians were awarded tasks suitable for light infantry troops. These included skirmishing with the enemy troops preceding a major battle, monitoring the motions of the enemy, storming the enemy's advanced posts, protecting the army rear from surprise attacks, and performing various other functions essential in early modern warfare. They were fairly successful in their missions, although on occasions they failed to rise to the challenge, which can perhaps be explained through their lack of discipline. On the other hand, it can also be argued that these shortcomings were actually a feature of the Austrian army as a whole. Furthermore, the Grenzers' self-will should not necessarily be interpreted as their disregard for their military duties, but rather as a sign that they had a specific way of perceiving their military profession. In most cases, the Grenzer from Lika displayed efficiency and resourcefulness while performing many dangerous military tasks.

\footnotetext{
${ }^{106}$ The Derby Mercury (Derby), online version, July 19, 1754, 2, https://www.britishnewspaperarchive. co.uk/ (last accessed on January 23, 2017).
} 
The newspapers which reported on their military activity certainly did not regard them as useless soldiers. Quite to the contrary, words of praise can be found for their exploits and conduct. Reports published in the contemporary newspapers not only offer an insight into the exploits of the Grenzer and other military troops during the War of the Austrian Succession, but also provide information concerning various features of military life in the $18^{\text {th }}$ century. They do not only tell tales of victorious or crushing battles, but also reveal many other circumstances which preceded and followed these major engagements. These other components played no small part in determining the final outcome of war and it is precisely in these minor and often neglected segments that the Grenzer, in this case Grenzer from Lika, were present and played a significant role.

The example of the Lycanians shows that, even though they may have deserved the reputation of unruly and defiant subjects, they nonetheless acknowledged their military duties, which they fulfilled when they were awarded their eagerly desired Grenzer status. They fiercely guarded their status and privileges, as fiercely as they fought and shed blood for their sovereign. Truth be told, their defiant and resilient nature may have, in fact, been the trait that enabled them to endure the hardships associated with military life in their own homeland, as well as in distant lands where they faced different threats from furious enemy troops, disgruntled local populace, and suspicious "friendly" forces. 


\section{Bibliography}

\section{Primary Sources}

Newspapers from the British Newspaper Archive (online), last accessed on January 12, 2018: http://www.britishnewspaperarchive.co.uk

The Aberdeen Press and Journal (Aberdeen, Scotland), 1748, 1752.

The Caledonian Mercury (Edinburgh, Scotland), 1743, 1744, 1745, 1746, 1747.

The Derby Mercury (Derby, England), 1742, 1743, 1744, 1745, 1746, 1747, 1752, 1754 .

The Ipswich Journal (Ipswich, England), 1743, 1747.

The Newcastle Courant (Newcastle upon Tyne, England), 1743, 1744, 1745, 1746, 1747.

The Stamford Mercury (Stamford, England), 1742, 1744, 1746, 1747.

The Scots Magazine (Edinburgh, Scotland), 1745, 1746, 1747.

Newspapers from ANNO - Austrian Newspapers Online, last accessed on January 12, 2018: http://anno.onb.ac.at/

Wienerisches Diarium (Vienna, Austria), 1742, 1743, 1744, 1745, 1746, 1747

\section{Published Sources}

Bach, Franz. Povijest Otočke pukovnije: o nastanku ovoga kraja, njegovim žiteljima i njihovim sudbinama. Trans. Manuela Svoboda, ed. Milan Kranjčević. Zagreb: Hrvatski institut za povijest; Otočac: Katedra Čakavskog sabora pokrajine Gacke, 2010.

Fras, Franz de Paula Julius. Cjelovita topografija Karlovačke vojne krajine. Gospić: Ličke župe, 1988.

Wrede, Alpfhons Freiherr von. Geschichte der k. und k. Wehrmacht. Die Regimenter, Corps, Branchenund Anstalten von 1618 bis Ende des XIX. Jahrhunderts, V. Band. Vienna: Seidel, 1903.

\section{Secondary Literature}

Antoljak, Stjepan. Bune pučana i seljaka u Hrvatskoj. Zagreb: Matica hrvatska, 1956.

Barker, Hannah. Newspapers, Politics and English Society 1695-1855. Harlow: Pearson Education, 2000. 
Basset, Richard. For God and Kaiser: The Imperial Austrian Army from 1619 to 1918. New Haven, CT: Yale University Press, 2015.

Black, Jeremy. European Warfare, 1660-1815. London: University College London, 1994.

Browning, Reed. "New Views on the Silesian Wars," The Journal of Military History 69 (2005), nr. 2: 521-534.

Browning, Reed. The War of the Austrian Succession. New York: St. Martin's Press, 1993.

Buczynski, Alexander. "Uspon i pad pandurskog pukovnika Franje baruna Trencka," in Memoari baruna Franje Trenck, ed. Alexander Buczynski, Milan Vrbanus, Mica Orban Kljajić. Slavonski Brod: Hrvatski institut za povijest, Podružnica za povijest Slavonije, Srijema i Baranje, 11-110.

Čulinović, Ferdo. Seljačke bune u Hrvatskoj. Zagreb: Seljačka sloga, 1951.

Duffy, Christopher. The Army of Maria Theresa: The Armed Forces of Imperial Austria, 1740-1780. North Pomfret, VT: David \& Charles, 1977.

Hochedlinger, Michael. Austria's Wars of Emergence: War, State and Society in the Habsburg Monarchy 1683-1797. London: Pearson Education, 2003.

Horvat, Rudolf. Lika i Krbava: povijesne slike, crtice i bilješke, ed. Nikola Bićanić. Zagreb: Savez hrvatskih ličkih zavičajnih klubova "Vila Velebita", 1993.

Howard, Michael. Rat u europskoj povijesti. Trans. Magdalena Najbar-Agičić. Zagreb: Srednja Europa, 2002.

Jurišić, Ivan. "Lika i Krbava od Velikog rata za oslobođenje do inkorporacije u Karlovački generalat (1683-1712)". Radovi - Zavod za hrvatsku povijest 37 (2005): 101-110.

Jurišić, Ivan. Karlovački generalat u reformama Habsburškoga dvorskog apsolutizma. Primjer Hildburghausenovih reformi (1737.-1749.). Doctoral dissertation, University of Zagreb, 1998.

Kruhek, Milan. “Turske utvrde i kule u Lici i Krbavi 1527. - 1689. Godine”. Senjski zbornik 40 (2013): 471-508.

Kukuljević Sakcinski, Ivan. Hrvati za nasljednoga rata. Zagreb: Dionička tiskara, 1877.

Marković, Mirko. Ličani kroz prošlost. Zagreb: Naklada Jesenski i Turk, 2001.

Moačanin, Fedor; Valentić, Mirko. Vojna krajina u Hrvatskoj. Zagreb: Povijesni muzej Hrvatske, 1981.

Rothenberg, Gunther Eric. The Austrian Military Border in Croatia, 1522-1747. Urbana, IL: The University of Illinois press, 1960. 
Rothenberg, Gunther Eric. The Military Border in Croatia, 1740-1881: A Study of an Imperial Institution. Chicago and London: The University of Chicago Press, 1966.

Ruff, Julius. Violence in Early Modern Europe. Cambridge: Cambridge University Press, 2001.

Starkey, Armstrong. War in the Age of Enlightenment, 1700-1789. Westport, CT: Paeger, 2003. 
Juraj Balić*

\section{U službi Njezina Veličanstva: novinska izvješća o ličkim krajišnicima tijekom Rata za austrijsko nasljeđe (1740. - 1748.)}

\section{Sažetak}

Područja Like i Krbave sačinjavala su dio teritorijalnih stečevina habsburških vladara nakon Velikog bečkog rata ili Rata Svete Lige (1683. - 1699.). Uključivanje ovih područja u sastav Hrvatsko-slavonske vojne krajine stvaralo je velike poteškoće za habsburške vlasti zbog prkosne naravi ovdašnjih stanovnika koji su uporno branili svoja prava i privilegije. Kao mnogi drugi krajišnici, Ličani ili "Lycanians," kako su bili oslovljavani u suvremenim britanskim novinama, pokrenuli bi bune svaki put kad bi osjetili da je njihov privilegirani položaj ugrožen. No, istovremeno su ovi i drugi krajišnici ne samo branili habsburške granice od Osmanlija, već su i ratovali u službi svojih vladara diljem Europe. Cilj ovoga rada jest istražiti ulogu i uspjeh ove posebne skupine krajišnika tijekom Rata za austrijsko nasljeđe (1740. - 1748.). Glavna pažnja pritom je usmjerena njihovu prikazu u suvremenim britanskim i austrijskim novinama koje su intenzivno pratile djelovanje raznih boraca tijekom spomenutog sukoba.

Ključne riječi: krajišnici, Vojna krajina, Lika i Krbava, Marija Terezija, Rat za austrijsko nasljeđe, ranomoderne novine, ranomoderno ratovanje

Juraj Balić, Hrvatski institut za povijest, Opatička 10, 10000 Zagreb, Republika Hrvatska, E-mail adresa: jura.balic@gmail.com 